\title{
SUITABILITY OF CORN STALK PULP FOR IMPROVING PHYSICAL STRENGTH PROPERTIES OF AGRO-RESIDUE PULP
}

\author{
OM PRAKASH MISHRA, SANDEEP KUMAR TRIPATHI and NISHI KANT BHARDWAJ \\ Avantha Centre for Industrial Research and Development, BILT Paper Mill Campus, \\ Yamuna Nagar, Haryana, India \\ ๑ Corresponding author: S. K. Tripathi, skt1973@rediffmail.com
}

Received August 13, 2019

Corn stalk was assessed in terms of its chemical constituents, pulping behavior, bleaching, morphological properties and physical strength properties. The effect of blending corn stalk pulp with wheat straw pulp on the physical strength properties of the resulting blend was studied for evaluating the potential of corn stalk to be used by agro-based paper industries. Corn stalk had alkali solubility of $41.8 \%$ and the following composition: $3.5 \%$ acetone extractives, $53.6 \%$ cellulose, $26.4 \%$ hemicelluloses and $20.0 \%$ Klason lignin. The requirement of alkali for obtaining unbleached pulp of kappa number 16.1 was $14.5 \%$ as $\mathrm{NaOH}$, while using soda-anthraquinone pulping. A fairly good pulp yield of $53.7 \%$ and pulp viscosity of $26.0 \mathrm{cP}$ were obtained for corn stalk. The pulp was easily bleached to the brightness of $88.4 \%$, using the elemental chlorine free bleaching sequence $\mathrm{D}_{0} \mathrm{E}_{\mathrm{OP}} \mathrm{D}$. The bleached pulp had an average fibre length of 0.93 $\mathrm{mm}$, width of $19.0 \mu \mathrm{m}$ and viscosity of $21.1 \mathrm{cP}$. The physical strength properties of the bleached corn stalk pulp were superior, specifically tensile index, to those of unbleached pulp, perhaps because of the interference of residual lignin during fibrillation, as well as of poor fibre bonding in unbleached pulp refining and sheet making. Physical strength properties, such as tear, tensile, burst indices and double fold number, of wheat straw pulp improved by $5.5 \%, 13.9 \%$, $22.1 \%$ and $57.6 \%$, respectively, upon blending with $35 \%$ corn stalk pulp.

Keywords: corn stalk pulp, wheat straw pulp, soda-AQ pulping, ECF bleaching, physical strength properties

\section{INTRODUCTION}

To prevent deforestation while fulfilling the demand for paper and paper products, agroresidue based raw materials are being utilized by the paper industry as alternative sources of fibre. Wheat straw, bagasse and rice straw are the main agro-residue based raw materials used by the paper industries for producing different types of unbleached and bleached grades of paper and boards. China, India and a few other Asian countries are using agro-based raw materials for papermaking because of lack of forest resources.

Maize or corn (Zea mays L.) is one of the most important cereal crops in the world. Each part of the maize plant (grains, leaves, stalk, tassel and cob) is utilized to produce a variety of food and non-food products. Worldwide, about $750,000,000$ bone dry metric tons corn stalk residue is available as a waste. ${ }^{1}$ The whole maize plant contains about $31.9 \%$ grain, $52.1 \%$ stalk residue, $11.5 \%$ cob and $4.5 \%$ husk. $^{2}$ Corn stalk is reported to have high hemicelluloses and low lignin contents, while its morphological characteristics are similar to those of hardwood species. Delignification of corn stalk using the soda-anthraquinone (soda-AQ) process is better than that of wood, as it requires lower temperature to get the desired kappa number of unbleached pulp, as compared to wood. ${ }^{3}$ The suitability of corn stalk has been also evaluated for making dissolving pulp using water and acid prehydrolysis, followed by kraft pulping and bleaching with HEHP sequence. ${ }^{3}$ Researchers have also reported that the chemical composition and morphological characteristics of corn stalk make it suitable for being used as an alternative raw material for producing pulp in combination with softwood, hardwood, pineapple leaf and Napier grass pulps. ${ }^{4-6}$ Researchers have also reported on the utilization of corn stalk for making particleboard and for the production of furfural. $^{7}$ Other researchers reported on the production of three-layer particleboard using corn stalk and industrial wood mixture, as well as urea formaldehyde as adhesive. ${ }^{8}$ 
However, scanty literature is available on soda-AQ pulping, ECF bleaching of corn stalk pulp and on the suitability of blending bleached corn stalk pulp with agro-residue based mill pulp. In the present study, corn stalk was evaluated with regard to its chemical constituents, morphological characteristics, chemical pulping using the sodaAQ process, elemental chlorine free (ECF) bleaching, followed by blending with wheat straw pulp to find its suitability for the agro-based paper industry.

\section{EXPERIMENTAL}

\section{Materials}

Corn stalk (Zea mays L.) was collected from north India and was chopped into small pieces of about 2-3 $\mathrm{cm}$ prior to pulping experiments. To determine the chemical composition of corn stalk, the material was ground in a Wiley mill as per Tappi T 257 sp-14 and screened on a 40 mesh sieve. The chemical constitutents, namely, $1 \% \mathrm{NaOH}$ solubility, acetone extractives, ash content and Klason lignin, were determined as per Tappi T $212 \mathrm{om}-07$, T $264 \mathrm{~cm}-07$, T 211 om-12, T 222 om-15, respectively. Cellulose, hemicelluloses and holocellulose were determined as per the methods provided by Updegraff, ${ }^{9}$ Deschatelets and Errest, ${ }^{10}$ and Wise. ${ }^{11}$ Wheat straw pulp bleached using the $\mathrm{D}_{0} \mathrm{E}_{\mathrm{OP}} \mathrm{D}$ sequence was collected from an agro-based paper mill situated in the northern part of India. The mill produces bleachable grade pulp mainly from wheat straw and bagasse. The mill pulp had the brightness of $82.2 \%$ and viscosity of $9.3 \mathrm{cP}$.

\section{Pulping}

Soda-AQ pulping was performed in an autoclave digester, consisting of six bombs of $2.5 \mathrm{~L}$ capacity. Maximum cooking temperature $\left(168{ }^{\circ} \mathrm{C}\right)$ was set for pulping the corn stalk. The initial temperature of the glycol bath was maintained at $150{ }^{\circ} \mathrm{C}$. The temperature was raised from $150{ }^{\circ} \mathrm{C}$ to $168^{\circ} \mathrm{C}$ in 20 min. Cooking at maximum temperature was done for $20 \mathrm{~min}$, using a fixed dose of anthraquinone of $0.05 \%$ on corn stalk. The pulps were screened using a Somerville screen with $0.15 \mathrm{~mm}$ slot size. Moisture content was analyzed as per Tappi T 412 om-11. Unbleached pulp was analyzed for kappa number and viscosity as per Tappi T 236 om-06 and T 230 om-08, respectively.

\section{Black liquor analysis}

After the end of the cooking process, the cooked mass was squeezed through a Buchner funnel and the black liquor (filtrate) was collected. The liquor was analysed for residual alkali as per T $625 \mathrm{~cm}-14$ and total solids as per T $650 \mathrm{om}-15$.

\section{Bleaching}

Bleaching of the pulp was carried out using the elemental chlorine free bleaching sequence $\mathrm{D}_{0} \mathrm{E}_{\mathrm{OP}} \mathrm{D}$, applying the conditions for the different stages of bleaching as given in Table 1 .

For evaluating the optical properties of the bleached pulps, handsheets were formed on a Buchner funnel as per Tappi test method T 218 sp-02. Brightness, whiteness, post colour number and viscosity of the pulps were tested as per ISO 2470 , ISO 11475, Tappi UM 200 and Tappi T 230 om-08, respectively.

\section{Fibre morphology}

The morphological properties, such as average fibre length, width, coarseness and fibre length distribution, of the corn stalk unbleached and bleached pulps were analyzed using an $\mathrm{L} \& \mathrm{~W}$ fibre tester as per Tappi T 271 om-07. Scanning electron microscopy (SEM) analysis of the unbleached and bleached corn stalk pulps was carried out using a JEOL JSM 6510 LV SEM, at 2500 resolution.

Table 1

Bleaching conditions in different stages

\begin{tabular}{lccc}
\hline Parameter & $\mathrm{D}_{0}$ & $\mathrm{E}_{\mathrm{OP}}$ & $\mathrm{D}$ \\
\hline Consistency $(\%)$ & 10 & 10 & 10 \\
Temperature $\left({ }^{\circ} \mathrm{C}\right)$ & 55 & 80 & 75 \\
Time $(\min )$ & 45 & 120 & 180 \\
\hline
\end{tabular}

\section{Physical strength properties}

Refining of unbleached and bleached corn stalk pulps to different freeness levels was carried out using a PFI mill as per Tappi T 248 sp-08. Laboratory handsheets were prepared from both refined and unrefined pulps, using a British handsheet former as per Tappi T 205 sp-06. The freeness of refined and unrefined pulps was measured as per Tappi T 227 om09. Physical strength properties, such as tensile, tear, burst indices and folding endurance, were analyzed as per Tappi T 220 sp-01. 


\section{RESULTS AND DISCUSSION}

\section{Proximate chemical analysis}

The results of proximate chemical analysis of the corn stalk and their comparison with those for different agro-residue pulps are given in Table 2. Corn stalk has $1.0 \%$ alkali solubility of $41.8 \%$, $3.52 \%$ acetone extractives, $53.6 \%$ cellulose, $26.4 \%$ hemicelluloses and $20.0 \%$ Klason lignin. Acetone extractives contain mainly waxes, fats, resins, tannins, gums etc. ${ }^{12}$ Ash and silica content in the corn stalk was significantly lower, as compared to those of other agro-residues, except bagasse. ${ }^{13-15}$ Earlier, the researchers reported contents of $27-28 \%$ hemicelluloses, $46.5 \%$ cellulose and $16.17 \%$ lignin in corn stalk, which were comparable with the values obtained in the present study. $^{16}$ Chesca et $a l .{ }^{17}$ reported significantly lower cellulose content of 34.6$42.1 \%$, pentosans of $17.6-20.7 \%$, holocellulose of 62.5-67.7\% and similar lignin content of 19.1$20.9 \%$, ash content of $4.5-5.7 \%$ for Romanian corn stalk, as compared to the chemical composition of Indian corn stalk reported in this paper.

\section{Soda-AQ pulping}

To optimize the alkali dose during pulping, alkali doses of 13.0, 14.5 and $16.0 \%$ as $\mathrm{NaOH}$ were applied to get unbleached pulp of kappa number $15 \pm 2$, which is generally kept by most agro-based paper mills. The detailed pulping results are given in Table 3. The pulping results showed that unbleached pulp with kappa number 16.1 was obtained using $14.5 \%$ alkali dose as sodium hydroxide. The screened yield was $53.7 \%$, with rejects content of $2.8 \%$, which was found quite similar in other agro-raw materials as well. With the increase in alkali dose from 13.0 to $16.0 \%$ during pulping, the kappa number of the pulp was reduced from 20.5 to 11.9 , and the screened pulp yield decreased from 56.0\% to $47.7 \%$. The viscosity of unbleached pulp of 26.0 cP appeared to be better than that of other agrobased unbleached pulps. Earlier, the researchers also reported $43.7 \%$ pulp yield with kappa number of 10.4 and pulp viscosity of $32.0 \mathrm{cP}$ for soda-AQ pulping of corn stalk. ${ }^{18}$ Chesca et al. ${ }^{17}$ reported very low pulp yield of $35.9 \%$, viscosity of $866 \mathrm{~mL} / \mathrm{g}$ and drainability of $19{ }^{\circ} \mathrm{SR}$ for unbleached soda pulp produced from Romanian corn stalk, as compared to that obtained for Indian corn stalk reported in this paper. Such difference may be due to the different origin of the corn stalk.

\section{Bleaching}

Unbleached pulp with kappa number 16.1 was bleached using the $\mathrm{D}_{0} \mathrm{E}_{\mathrm{OP}} \mathrm{D}$ bleaching sequence, by applying an optimized kappa factor of 0.28 in the $\mathrm{D}_{0}$ stage of bleaching. The brightness and whiteness of the bleached corn stalk pulp achieved $88.4 \%$ ISO and 81.8 points, respectively, which is significantly better than these corresponding values for other agro-based pulps. The brightness reversion measured as post colour number of 0.78 was also comparatively lower than that of other agro-residue based raw pulps. Bleached pulp viscosity of $21.1 \mathrm{cP}$ was significantly higher than that of other straw pulps. ${ }^{18}$

Table 2

Proximate chemical analysis of corn stalk compared to other agro-based raw materials

\begin{tabular}{lcccc}
\hline \multirow{2}{*}{ Constituent } & \multicolumn{3}{c}{ Value (\%) } \\
\cline { 2 - 5 } & $\begin{array}{c}\text { Corn stalk } \\
\text { (present study) }\end{array}$ & Wheat straw ${ }^{13}$ & Rice straw $^{14}$ & Bagasse $^{15}$ \\
\hline Hot water solubility & $11.4 \pm 0.3$ & $11.1 \pm 0.7$ & 7.3 & - \\
$1 \%$ NaOH solubility & $41.8 \pm 1.1$ & $28.2-35.2$ & 57.7 & 32.7 \\
Acetone extractives & $3.52 \pm 0.15$ & $2.3 \pm 0.2$ & $0.56^{*}$ & $2.7^{*}$ \\
Cellulose & $53.6 \pm 1.7$ & $36.6-47.8$ & $28-36$ & 47.2 \\
Hemicellulose & $26.4 \pm 1.2$ & $23.6-28.1$ & $23-28$ & 24.7 \\
Klason lignin & $20.0 \pm 0.9$ & $16.4-19.9$ & $12-16$ & 19.2 \\
Holocellulose & $77.5 \pm 1.6$ & $64.4-72.7$ & - & 71.5 \\
Ash & $4.65 \pm 0.2$ & $5.2-7.1$ & $15-20$ & 2.6 \\
Silica & $0.65 \pm 0.03$ & $4.1 \pm 0.2$ & $9-14$ & - \\
\hline
\end{tabular}

*Alcohol benzene extractives 
Table 3

Soda-AQ pulping of corn stalk

\begin{tabular}{lccc}
\hline Parameter & \multicolumn{3}{c}{ Results } \\
\hline Alkali as NaOH (\%) & 13.0 & 14.5 & 16.0 \\
\hline \multicolumn{4}{c}{ Pulp properties } \\
\hline Kappa number & 20.3 & 16.1 & 11.9 \\
Unscreened yield (\%) & 62.7 & 56.5 & 49.3 \\
Rejects (\%) & 6.7 & 2.8 & 1.6 \\
Screened yield (\%) & 56.0 & 53.7 & 47.7 \\
Brightness (\%ISO) & 33.8 & 35.1 & 37.5 \\
Viscosity (cP) & -- & 26.0 & -- \\
\hline \multicolumn{4}{c}{ Black liquor properties } \\
\hline Total solids (\%) & 12.2 & 12.9 & 13.6 \\
RAA g/L as NaOH & 2.6 & 4.1 & 6.2 \\
\hline
\end{tabular}

Table 4

Bleaching of corn stalk pulp using $\mathrm{D}_{0} \mathrm{E}_{\mathrm{OP}} \mathrm{D}$ bleaching sequence

\begin{tabular}{lc}
\hline Parameter & Results \\
\hline Kappa number & 16.1 \\
\hline $\mathrm{D}_{\mathrm{O}}$ stage & \\
\hline End pH & 2.3 \\
Residual $\mathrm{ClO}_{2}(\mathrm{ppm})$ & 12.1 \\
\hline $\mathrm{E}_{\mathrm{OP}}$ stage & \\
\hline End pH & 11.3 \\
Residual $\mathrm{H}_{2} \mathrm{O}_{2}(\mathrm{ppm})$ & 3.4 \\
Kappa number & 1.2 \\
Brightness (\% ISO) & 82.0 \\
\hline D stage & \\
\hline End pH & 3.3 \\
Residual $\mathrm{ClO}(\mathrm{ppm})$ & 20 \\
Brightness (\% ISO) & 88.4 \\
Whiteness (CIE) & 81.8 \\
Viscosity (cP) & 21.1 \\
Post color number & 0.78 \\
Shrinkage (\%) & 6.9 \\
\hline
\end{tabular}

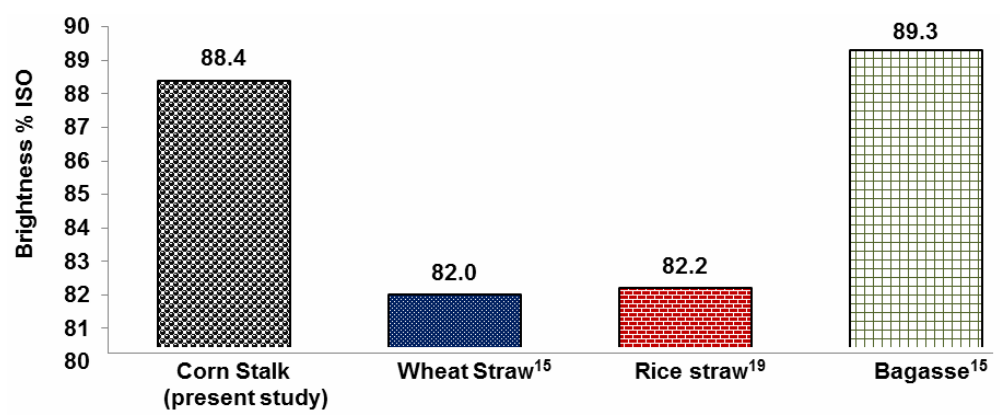

Figure 1: Brightness evolution of different agro-residue pulps using $\mathrm{D}_{0} \mathrm{E}_{\mathrm{OP}} \mathrm{D}$ sequence

Earlier research reported having achieved up to 80.0 point whiteness, while using organosolv pulping, followed by TCF bleaching sequences, for corn stalk pulp. ${ }^{19}$ Detailed ECF bleaching results for corn stalk are provided in Table 4. The development of pulp brightness during bleaching of corn straw pulp was found comparable with that of bagasse pulp and superior to that of wheat straw and rice straw pulps, as shown in Figure 1.

\section{Fibre morphology}

Detailed morphological properties of unbleached and bleached corn stalk pulps are given in Table 5. Average fibre length and width 
of unbleached and bleached cork stalk pulps were of $0.96 \mathrm{~mm}$ and $19.3 \mu \mathrm{m}$, and of $0.93 \mu \mathrm{mm}$ and $19.0 \mu \mathrm{m}$, respectively. The fibre length and width of corn stalk pulp were comparatively higher than earlier reported values $(0.818 \mathrm{~mm}$ fibre length and $17.5 \mu \mathrm{m}$ fibre width) for wheat straw pulp. ${ }^{13}$ Several other researchers have reported on the morphological properties of corn stalk pulp as being comparable to those of hardwood pulp. ${ }^{16,20}$ The coarseness of the bleached corn stalk pulp, i.e. $94.1 \mu \mathrm{g} / \mathrm{m}$, was also higher than an earlier reported coarseness of $71.8 \mu \mathrm{g} / \mathrm{m}$ for ECF bleached wheat straw pulp. ${ }^{13}$ Higher coarseness of corn stalk pulp may result in higher physical strength properties of paper handsheets prepared from it, as compared to those of paper prepared from wheat straw pulp.

SEM micrographs of unbleached and bleached corn stalk pulps are shown in Figure 2 and Figure 3 , respectively. ECF bleaching of pulp facilitates the fibrillation of pulp fibers. More fibrils are visible in the bleached corn stalk pulp, as compared to the unbleached pulp. Improved fibrillation in bleached pulp may result in higher physical strength properties, as compared to those of unbleached pulp. Other authors have also reported an improvement in physical strength properties due to improved fibrillation, specifically tensile index..$^{21,22}$

\section{Physical strength properties of corn stalk pulps}

Physical strength properties of unbleached and bleached corn stalk pulps, at different freeness levels, are given in Table 6. The unbleached and bleached corn stalk pulps presented Canadian standard freeness (CSF) of $490 \mathrm{~mL}$ and $480 \mathrm{~mL}$, respectively. These pulps were refined further to get CSF of about $400 \mathrm{~mL}$ and $350 \mathrm{~mL}$ for developing strength properties. The unbleached pulp required 150 and 550 PFI mill revolutions and the bleached pulp required 150 and $500 \mathrm{PFI}$ revolutions to obtain pulps of about $400 \mathrm{~mL}$ and $350 \mathrm{~mL}$ CSF, respectively. The unrefined unbleached corn stalk pulp had tensile, burst, tear indices and double fold number of $49.1 \mathrm{~N} . \mathrm{m} / \mathrm{g}$, $3.80 \mathrm{kN} / \mathrm{g}, 7.53 \mathrm{mN} . \mathrm{m}^{2} / \mathrm{g}$ and 86 , respectively. The physical strength properties of the unbleached corn stalk pulp were improved upon refining the pulp to $405 \mathrm{~mL} \mathrm{CSF}$. Further increase in the extent of refining improved the physical strength properties, except tear index.

Table 5

Morphological properties of unbleached and bleached corn stalk pulps

\begin{tabular}{lcc}
\hline Parameter & Unbleached pulp & Bleached pulp \\
\hline Average fibre length $(\mathrm{mm})$ & 0.96 & 0.93 \\
Width $(\mu \mathrm{m})$ & 19.3 & 19.0 \\
Coarseness $(\mu \mathrm{g} / \mathrm{m})$ & 95.7 & 94.1 \\
Length distribution & & \\
$0.2-0.5 \mathrm{~mm}$ & 32.6 & 34.4 \\
$0.5-1.5 \mathrm{~mm}$ & 47.9 & 47.2 \\
$1.5-3.0 \mathrm{~mm}$ & 18.2 & 16.7 \\
$>3.0 \mathrm{~mm}$ & 1.3 & 1.7 \\
\hline
\end{tabular}

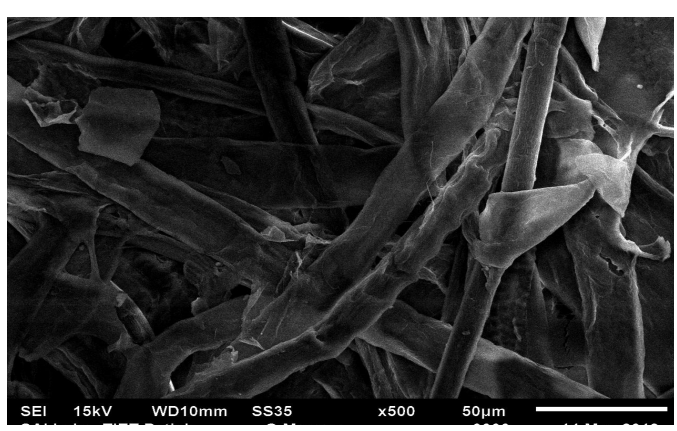

Figure 2: SEM micrograph of unbleached corn stalk pulp

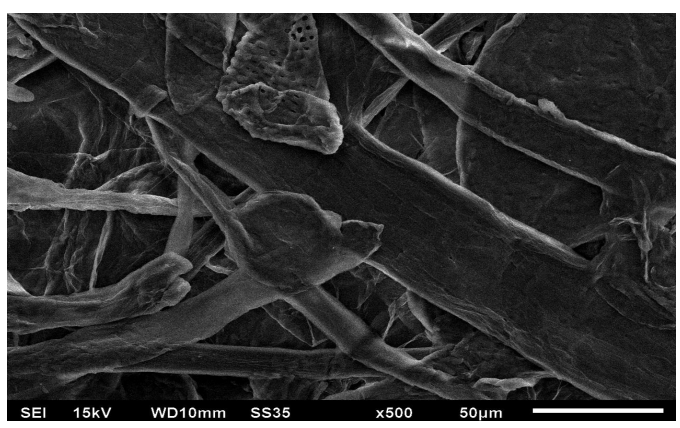

Figure 3: SEM micrograph of bleached corn stalk pulp 
Table 6

Physical strength properties of unbleached and bleached corn stalk pulps

\begin{tabular}{lcccccc}
\hline Parameter & \multicolumn{3}{c}{ Unbleached pulp } & \multicolumn{3}{c}{ Bleached pulp } \\
\hline No. of revolutions & 0 & 150 & 550 & 0 & 150 & 500 \\
CSF $(\mathrm{mL})$ & 490 & 405 & 345 & 480 & 405 & 345 \\
Bulk (cc/g) & 1.32 & 1.30 & 1.32 & 1.30 & 1.29 & 1.30 \\
Tensile index (N.m/g) & 49.1 & 58.7 & 60.8 & 54.2 & 61.5 & 63.9 \\
Burst index (kN/g) & 3.80 & 4.82 & 5.09 & 4.16 & 4.85 & 5.37 \\
Tear index $\left(\mathrm{mN} . \mathrm{m}^{2} / \mathrm{g}\right)$ & 7.53 & 7.94 & 7.69 & 8.73 & 8.28 & 7.29 \\
Double fold number & 86 & 319 & 349 & 89 & 303 & 356 \\
\hline
\end{tabular}

Table 7

Physical strength properties of different blends of corn stalk and wheat straw pulps

\begin{tabular}{lccccc}
\hline \multirow{2}{*}{ Parameter } & \multicolumn{5}{c}{ Wheat straw : corn stalk } \\
\cline { 2 - 5 } & $100: 0$ & $100: 0$ & $70: 30$ & $65: 35$ & $60: 40$ \\
\hline No. of revolutions & 0 & 200 & 200 & 250 & 300 \\
${ }^{\circ} \mathrm{SR}$ & 492 & 420 & 430 & 430 & 425 \\
Bulk $(\mathrm{cc} / \mathrm{g})$ & 1.36 & 1.31 & 1.29 & 1.30 & 1.28 \\
Tensile index $(\mathrm{N} . \mathrm{m} / \mathrm{g})$ & 41.5 & 53.2 & 56.5 & 57.5 & 60.6 \\
Burst index $(\mathrm{kN} / \mathrm{g})$ & 3.56 & 3.89 & 4.54 & 4.64 & 4.75 \\
Tear index $\left(\mathrm{mN} . \mathrm{m}^{2} / \mathrm{g}\right)$ & 7.21 & 7.32 & 7.43 & 7.52 & 7.72 \\
Double fold number & 27 & 85 & 101 & 126 & 134 \\
\hline
\end{tabular}

Daud et $a .^{23}$ reported very low tensile index, of $9.1 \mathrm{Nm} / \mathrm{g}$, tear index of $1.2 \mathrm{Nm}^{2} / \mathrm{g}$ and comparable burst index of $6.6 \mathrm{kPa} \cdot \mathrm{m}^{2} / \mathrm{g}$ for unbleached corn stalk pulp of Malaysian origin, as compared to the corresponding values of the corn stalk pulp reported in this study. The bleached corn stalk pulp had tensile index of 54.2 N.m/g, burst index of 4.16 , tear index of 8.73 and double fold number of 89 . Upon refining of the pulp, the tear index of the bleached pulp was reduced even when refining the pulp to $405 \mathrm{~mL}$ CSF. However, other properties, such as tensile and burst indices, as well as double fold number, were improved.

\section{Physical strength properties of different blends of corn stalk and wheat straw pulp}

The bleached unrefined wheat straw pulp was blended with bleached unrefined corn stalk pulp in ratios of 70:30, 65:35 and 60:40. The bleached wheat straw pulp and different blends were refined to obtain pulps having CSF of about 425 $\mathrm{mL}$ and the effect of blending on the physical strength properties of handsheets was analyzed. Detailed results of physical strength properties for the different blends of corn stalk and wheat straw pulps are given in Table 7. The bleached wheat straw pulp had a tensile index of $52.3 \mathrm{~N} . \mathrm{m} / \mathrm{g}$, burst index of 3.89, tear index of 7.32 and double fold number of 85 . Blending corn stalk pulp with the bleached wheat straw pulp significantly improved the physical strength properties, namely, tensile index by $13.9 \%$, burst index by $22.1 \%$, tear index by $5.5 \%$ and double fold by $57.6 \%$. The reason behind the improvement in physical strength properties may be the higher average fiber length and coarseness of corn stalk pulp, as compared to those of wheat straw pulp.

\section{CONCLUSION}

The chemical composition of corn stalk is similar to that of other agro-based raw materials, such as wheat straw and sugarcane bagasse. To produce unbleached pulp with a kappa number of 14.5 , screened pulp yield of $53.7 \%$ and viscosity of $26.0 \mathrm{cP}$, the alkali requirement was of $14.5 \%$ as $\mathrm{NaOH}$, while using soda-AQ pulping for corn stalk. The pulp produced was easily bleachable to a brightness of $88.4 \%$ ISO. Based on the findings, it can be concluded that corn stalk can be utilized for papermaking by agro-based paper mills as its pulping behavior and bleaching response are similar to those of other agro-residue based raw materials. Blending corn stalk pulp with wheat straw pulp improved the physical strength properties of the resulting blend, which may help agro-residue based paper mills to improve their product quality.

\section{REFERENCES}

1 T. Y. A. Fahmy, F. Mobarak, M. E. J. Sakhawy and M. H. Fadi, Int. J. Chem. Tech. Res., 10, 425 (2017), 
http://sphinxsai.com/2017/ch_vol10_no2/2/(425448)V10N2CT.pdf

2 M. Singh, S. S. Thakur, R. Chandel and A. Sharma, Agric. Eng. Today, 39, 3 (2015), https://www.indianjournals.com/ijor.aspx?target=ijor:a et $\&$ volume $=39 \&$ issue $=3 \&$ article $=001$

3 J. Behin, F. Mikaniki and Z. Fadaei, Iran. J. Chem. $\begin{array}{llll}\text { Eng., } & \text { 5, } & 14\end{array}$ http://www.ijche.com/article_15180.html

4 Z. Daud, M. Z. Mohd Hatta, A. S. M. Kassim, H. Awang and A. M. Aripin, Aust. J. Basic Appl. Sci., 7, 401 (2013), http://ajbasweb.com/old/ajbas/2013/July/401-405.pdf

5 Z. Daud, M. Z. M. Hatta, A. S. M. Kassim, H. Awang and A. M. Aripin, Bioresources, 9, 872 (2014), https://bioresources.cnr.ncsu.edu/issues/vol9issue 1/page/7/

6 M. O. Aremu, S. O. Aperolola and O. O. Dabonyan, Eur. Sci. J., 11, 146 (2015), https://eujournal.org/index.php/esj/article/view/6359/6 110

7 K. L. Kadam and J. D. McMillan, Bioresour. Technol., $\quad \mathbf{8 8 ,} \quad 17 \quad$ (2003), https://doi.org/10.1016/S0960-8524(02)00269-9

8 C. Guler, H. I. Sahin and S. Yeniay, Wood Res., 61, 299

http://www.woodresearch.sk/articles.php?volume=14\& issue $=53$

9 D. M. Updegraff, Anal. Biochem., 32, 420 (1969), https://doi.org/10.1016/S0003-2697(69)80009-6

10 L. Deschatelets and K. C. U Errest, Appl. Microb. Biotech., 24, $379 \quad$ (1986) https://doi.org/10.1007/BF00294594

11 L. E. Wise, M. Murphy and A. A. D'Addieco, Paper Trade J., 122, 35 (1946).

12 J. Shakhes, M. A. B. Marandi, F. Zeinaly, A. Saraian and T. Saghafi, BioResources, 6, 4481 (2011), https://bioresources.cnr.ncsu.edu/issues/vol6issue4/page/7/
13 S. K. Tripathi, N. K. Bhardwaj, H. R. Ghatak, Cellulose Chem. Technol., 53, 105 (2019), https://doi.org/10.35812/CelluloseChemTechnol.2019. 53.12

14 W. Sridach, Suranaree J. Sci. Technol., 17, 105 (2010), http://citeseerx.ist.psu.edu/viewdoc/download?doi=10. 1.1.471.6632\&rep=rep1\&type $=$ pdf

15 S. Tripathi, S. Singh, A. Gangwar, O. P. Mishra et al., IPPTA J., 25, 121 (2013), https://www.ippta.co

16 A. Ahmed and J. Y. Zhu, in Procs. $3^{\text {rd }}$ International Symposium on Energy Technology of Pulping and Paper Making, November 8-10, 2006, pp. 1-4, South China University of Technology Press, https://www.scut.edu.cn/en/

17 A. M. Chesca, R. Nicu, B. M. Tofanica, A. C. Puitel, R. Vlase et al., Cellulose Chem. Technol., 52, 645 (2018),

http://www.cellulosechemtechnol.ro/pdf/CCT78(2018)/p.645-653.pdf

18 S. Ates, I. Deniz, H. Kirci, C. Atik and O. T. Okan, Turk. J. Agric. For., 39, 144 (2015), https://doi.org/10.3906/tar-1403-41

19 V. Barbash, I. Trembus and J. Nagorna, Chem. Chem. Technol., $\quad 6, \quad 83 \quad$ (2012), https://doi.org/10.23939/chcht06.01.083

20 M. Byrd, H. Jameel, S. Warby and W. Johnson, in Procs. TAPPI Engineering, Pulping and Environmental Conference, November 5-8, Atlanta, Georgia, USA, pp. 1, 2006, https://www.tappi.org

21 T. Kang and H. Paulapuro, Pulp Pap. Can., 107, 171 (2006), www.pulpandpapercanada.com

22 X. Wang, T. C. Maloney and H. Paulapuro, Pap. Рuи, 77, 1 (2007), www.paperijapuu.fi

23 Z. Daud, M. Z. M. Hatta and H. Awang, Procedia Soc. Behav. Sci., 195, $2047 \quad$ (2015), https://doi.org/10.1016/j.sbspro.2015.06.226 